\title{
Intracellular electrolytes in cardiac and skeletal muscle in fatal digitalis intoxication ${ }^{1}$
}

\author{
T. DYCKNER, U. DE FAIRE, AND P. O. WESTER \\ From the Medical Department, Karolinska Institutet at Serafimerlasarettet, Stockholm, Sweden
}

\begin{abstract}
Samples from cardiac and skeletal muscle were obtained immediately after death in a case of fatal digitalis intoxication. Intra- and extracellular electrolytes were determined by atomic absorption spectrophotometry. No changes were found in the extracellular electrolytes, and only modest changes were noted in skeletal muscle. In cardiac muscle, however, profound electrolyte disturbances were recorded with an inward shift of sodium and an outward shift of potassium. This signifies an extensive and early inhibition of the membrane ATPase in cardiac muscle and stresses the importance of immediate and vigorous treatment of the intracellular electrolyte disturbances with a view to suppressing serious and potentially lethal arrhythmias.
\end{abstract}

Intoxication by digitalis glycosides usually results from therapeutic overdosage (Lown and Levine, 1954; Mason and Braunwald, 1968; Surawicz and Mortelmans, 1969) but an increasing number of cases caused by the ingestion of pills with suicidal intent or by accident have been reported in the past decade (McNamara et al., 1964; Buchanan, 1967; Smith and Willerson, 1971; Bismuth et al., 1973; Steentoft, 1973). These cases present difficult therapeutic problems but they also afford opportunities to record the effects of gross digitalis overdosage. The cause of early malignant arrhythmias in patients with serious digitalis intoxication is generally considered to be disturbance of the electrolyte balance across the cell membrane. There may be very little evidence of these electrolyte disturbances in serum determinations. This is illustrated by a fatal case of digitalis intoxication in which we were able to study the intracellular electrolytes.

\section{Case history}

The patient, a woman of 64 , was being treated with digoxin $0.25 \mathrm{mg}$ per day because of heart failure. With the intention of committing suicide she ingested 80 to 100 tablets, corresponding to 20 to $25 \mathrm{mg}$ digoxin, and was admitted to the emergency ward a few hours later. She was then fully conscious but complained of breathlessness and had a variable

1This work was supported by the Swedish National Association against Heart and Chest Diseases. degree of atrioventricular block. Despite the risk of vagal stimulation, she was given a gastric lavage with 4.5 litres of carbon suspension; only one tablet was found in the return fluid. The patient was then transferred to the CCU, where a temporary pacemaker was immediately inserted. During this procedure she developed ventricular fibrillation, which resisted all therapy including external DC shock, artificial respiration, external heart massage, and correction of the acidosis. There were no myocardial contractions despite satisfactory pacing electrode positioning as judged radiologically. The patient died four hours after admission. Blood samples for determination of electrolytes and digoxin had been taken on admission to the hospital.

\section{Methods}

Immediately after death, samples were taken from skeletal muscle and the right and left myocardium. A piece of the vastus lateralis muscle was obtained, using the instrument for biopsy described by Bergström (1962). All visible connective tissue and fat were removed and the specimens ( 40 to $80 \mathrm{mg}$ ) were weighed repeatedly on a Cahn 4700 electromagnetic balance. The material was then dried at $100^{\circ} \mathrm{C}$ to constant weight and the water content was calculated. Fat content was obtained after extraction with petroleum ether. The specimens were analysed for sodium, potassium, and magnesium by atomic absorption spectrophotometry after extraction with 
Table 1 Muscle electrolytes in a case of fatal digitalis intoxication

\begin{tabular}{|c|c|c|c|c|c|c|c|c|c|c|}
\hline & \multicolumn{2}{|c|}{$\begin{array}{l}\text { mmol/kg } \\
\text { intracellular water }\end{array}$} & \multicolumn{4}{|c|}{ mmol/kg wet weight } & \multicolumn{4}{|c|}{ mmol/100 $g$ fat free dry solids (FFDS) } \\
\hline & $N a$ & $\boldsymbol{K}$ & $N a$ & $\boldsymbol{K}$ & $M g$ & $C l$ & $\mathrm{Na}$ & $\boldsymbol{K}$ & $M g$ & $C l$ \\
\hline $\begin{array}{l}\text { Skeletal muscle } \\
\text { Left myocardium } \\
\text { Right myocardium }\end{array}$ & $\begin{array}{l}38 \cdot 0 \\
167 \\
122\end{array}$ & $\begin{array}{l}167 \\
106 \\
89 \cdot 0\end{array}$ & $\begin{array}{l}50 \cdot 2 \\
122 \\
102\end{array}$ & $\begin{array}{l}81 \cdot 0 \\
61 \cdot 4 \\
47 \cdot 3\end{array}$ & $\begin{array}{l}7 \cdot 00 \\
6 \cdot 90 \\
5 \cdot 95\end{array}$ & $\begin{array}{l}25 \cdot 6 \\
21 \cdot 9 \\
31 \cdot 1\end{array}$ & $\begin{array}{l}26 \cdot 5 \\
55 \cdot 1 \\
53 \cdot 4\end{array}$ & $\begin{array}{l}42 \cdot 6 \\
27 \cdot 7 \\
24 \cdot 8\end{array}$ & $\begin{array}{l}3 \cdot 70 \\
3 \cdot 36 \\
3 \cdot 11\end{array}$ & $\begin{array}{c}13 \cdot 5 \\
9 \cdot 87 \\
16 \cdot 3\end{array}$ \\
\hline
\end{tabular}

$1 \mathrm{~N}$ nitric acid in quartz tubes. Chloride was calculated indirectly after precipitation with silver nitrate.

The intra- and extracellular electrolyte concentrations were determined on the basis of the assumption that chloride is freely diffusible across the cell membrane. The Nernst equation (Conway, 1957) was used to get the actual distribution, assuming a resting membrane potential of $87.2 \mathrm{mV}$ (Bolte et al., 1963). With the aid of the total water and chloride content in the sample and the extracellular concentration of chloride corrected for a Donnan factor and a factor for plasma water, it is possible to estimate the intracellular electrolyte concentrations (Graham et al., 1967; Bergström and Bittar, 1969). Digoxin was determined by the radioimmunoassay method (Smith et al., 1969).

\section{Results}

Serum analyses showed sodium 144 , potassium 4.9 , and chloride $105 \mathrm{mmol} / \mathrm{l}$, urea $3.34 \mathrm{mmol} / \mathrm{l}$, and digoxin $30 \mathrm{ng} / \mathrm{ml}$ (therapeutic range $1 \cdot 5-2 \cdot 0$ ).

Samples from skeletal muscle showed an ordinary intracellular potassium concentration, $166 \mathrm{mmol} / \mathrm{kg}$ intracellular water, well in accord with the values reported by Bergström (1962) in a healthy population (143 to $191 \mathrm{mmol} / \mathrm{kg}$ intracellular water). The intracellular sodium concentration was raised, $38.0 \mathrm{mmol} / \mathrm{kg}$ intracellular water (normal maximum value $10.9 \mathrm{mmol} / \mathrm{kg}$ intracellular water); the chloride concentration, $13.5 \mathrm{mmol} / 100 \mathrm{~g}$ fat-free dry solids (FFDS) was near the upper limit of normal, $14.0 \mathrm{mmol} / 100 \mathrm{~g}$ FFDS. Intracellular water was within normal limits, $256 \mathrm{~g} / 100 \mathrm{~g}$ FFDS (normal 231-315 g/100 g FFDS). Magnesium was decreased, $3.70 \mathrm{mmol} / 100 \mathrm{~g}$ FFDS (normal 3.90$4 \cdot 70 \mathrm{mmol} / 100 \mathrm{~g}$ FFDS).

Analyses of the samples from the right and left ventricular myocardium revealed a probable intracellular potassium deficit with values of 88.7 and $106 \mathrm{mmol} / \mathrm{kg}$ intracellular water, respectively. The value for intracellular sodium concentration was about 3 times higher than the corresponding value in the skeletal muscle, 122 and $167 \mathrm{mmol} / \mathrm{kg}$ intracellular water, respectively. The chloride concentration in both the left and the right ventricular myocardium was low compared with the values given in Handbook of Biological Data (Spector, 1956). Intracellular water was normal. Low values for magnesium were noted in both the left $(3.36$ $\mathrm{mmol} / 100 \mathrm{~g}$ FFDS) and the right $(3.11 \mathrm{mmol} /$ $100 \mathrm{~g}$ FFDS) ventricular myocardium. All the electrolyte values found are shown in Table 1 and normal values are presented for comparison in Table 2.

\section{Discussion}

It is generally considered that Na-K-ATPase is the receptor for the toxic manifestations of cardiac glycosides. The toxic effects result from inhibition of the enzyme, which leads to an inhibition of the active transport of sodium out of the cell (Repke, 1965; Mason and Braunwald, 1968). This, in turn, causes an intracellular accumulation of sodium and, secondarily, an intracellular loss of potassium and increased inflow of chloride into the cell with an

Table 2 Reported mean values of muscle electrolytes (in mmol/kg wet weight) in healthy subjects and in patients with cardiac decompensation treated with digitalis (Widdowson and Dickerson, 1964)

\begin{tabular}{|c|c|c|c|c|c|c|c|c|}
\hline & \multicolumn{4}{|c|}{ No digitalis } & \multicolumn{4}{|c|}{ Digitalis } \\
\hline & $\mathrm{Na}$ & $K$ & $M g$ & $\mathrm{Cl}$ & $\mathrm{Na}$ & $K$ & $\mathbf{M g}$ & $\mathrm{Cl}$ \\
\hline $\begin{array}{l}\text { Skeletal muscle } \\
\text { Left myocardium } \\
\text { Right myocardium }\end{array}$ & $\begin{array}{l}36 \cdot 3 \\
44 \cdot 7 \\
47 \cdot 8\end{array}$ & $\begin{array}{l}92 \cdot 2 \\
78 \cdot 5 \\
56 \cdot 2\end{array}$ & $\begin{array}{l}8 \cdot 35 \\
8 \cdot 50 \\
8 \cdot 25\end{array}$ & $\begin{array}{l}22 \cdot 1 \\
38 \cdot 0 \\
39 \cdot 5\end{array}$ & 43.8 & 73.5 & & $38 \cdot 2$ \\
\hline
\end{tabular}


expansion of cellular volume by the attraction of water (Page, 1964). The findings in the present study are in agreement with this theory.

In the calculation of the intracellular electrolyte concentration the normal value of $87.2 \mathrm{mV}$ for the resting membrane potential (RMP) was used. However, in the patient concerned it is likely that there will have been some changes in the resting membrane potential due to the effect of the digitalis (Rosen et al., 1973), and the repeated DC shocks (Lown et al., 1965; Kleiger and Lown, 1966). Even extreme changes of resting membrane potential, however, amounting to $\pm 25 \mathrm{mV}$, which is far in excess of what is thought to be compatible with life (Graham et al., 1967), will alter the calculated concentration of the intracellular electrolytes by no more than \pm 3 per cent, apart from the intracellular sodium concentration of skeletal muscle, which will change by +13 or -2.5 per cent according to the direction of the change of the RMP. In the physiological range of $87.2 \mathrm{mV} \pm 10 \mathrm{mV}$, however, the changes will in all cases be well under 4 per cent. Thus the amount of the total chloride content calculated to be intracellular is relatively insensitive to changes in resting membrane potential, and this does not contribute a significant error in the calculation of extracellular water and hence of the intracellular electrolytes.

DC shocks will affect the cellular membranes and transiently the resting membrane potential, resulting in a loss of intracellular potassium. The change in resting membrane potential per se does not alter the calculated intracellular electrolyte concentrations significantly, but the supposed continuous leakage of potassium from the cells after the DC shocks (Kleiger and Lown, 1966) may have contributed to the extreme electrolyte disturbances recorded. DC shocks enhance the potassium losses induced by digitalis (Lown et al., 1965). In the present case, however, the electrolyte changes depending on digitalis were obviously severe enough to induce ventricular fibrillation, which was treated by DC shocks, probably resulting in a further enhancement of the already existing intracellular potassium deficit.

The effect of the electrolyte disturbances will be a fall in the potential difference over the cell membrane. This is probably the main cause of ectopic arrhythmias, which is one of the earliest cardiac manifestations of digitalis intoxication. When more potassium is lost from the intracellular space, the membrane potential approaches still closer to the threshold of excitation. Paradoxically, it will now be more difficult to accomplish an excitation of the cell. The reason for this is that the sodium flow, which gives rise to the fast depolarisation of the cell (phase 0 ), is proportional to the magnitude of the resting potential. The resting potential has fallen on account of the potassium losses, and ultimately enough sodium flow to accomplish an excitation of the cell cannot be mobilised. The muscle is now unable to contract or conduct further because of depolarisation block. Both hyperexcitability and non-excitability may thus be a feature of digitalis intoxication, depending on the degree of intracellular potassium loss and/or hyperkalaemia and the threshold potential of cardiac conducting and contractile tissue (Langer, 1972). If the potassium losses from the intracellular space are large, this may result in hyperkalaemia, which most reports in recent years consider to be a sign of a poor prognosis (Smith and Willerson, 1971; Bismuth et al., 1973; Beck et al., 1974). Bismuth et al. (1973) observed increased values of serum potassium in patients intoxicated with digitalis. The increase in the fatal cases was more pronounced than in the survivors. At the same time no correlation was found between the amount of digitalis ingested and mortality. Thus he considered the hyperkalaemia to be a measure of the extent of inhibition of membrane ATPase. In the present case, samples for serum electrolytes were obtained only on admission a few hours after the digitalis intake and at that early stage there was no hyperkalaemia.

The potassium concentration in serum correlates only indirectly with the myocardial threshold for digitalis toxicity. The critical factor is probably the potassium concentration in the myocardial cell, or rather the potassium gradient over the cell membrane (Lown et al., 1960).

In the present case the electrolyte disturbances were much more pronounced in cardiac than in skeletal muscle, which may be explained by a higher affinity of digitalis for heart muscle than skeletal muscle or a greater resistance to digitalis in skeletal muscle. Doherty et al. (1967) studied the distribution and concentration of tritium-labelled digoxin in 4 cases and found the highest concentration in myocardium, kidney, and liver; the level in skeletal muscle was far lower, about $1 / 8$ of the concentration in the myocardium per gram wet weight.

In the present case the intracellular electrolyte pattern in skeletal muscle may be interpreted as the start of a sodium retention in the cell which has not yet resulted in the anticipated secondary increase in the loss of potassium. In the myocardium, however, the changes are already pronounced. This may be the result of the discrepancy in digoxin concentration between skeletal muscle and myocardium reported by Doherty et al. (1967). In the present case the intake of digitalis preceded death by only 6 to 7 hours, which indicates that pronounced intra- 
cellular myocardial electrolyte disturbances may develop rapidly. Treatment should, therefore, take the electrolyte disturbances into account with a view to suppressing serious arrhythmias, which are often the immediate cause of death in severe digitalis intoxication.

In view of the inhibition of membrane ATPase by digitalis (Bonting et al., 1962), there seem to be good theoretical reasons for using magnesium in digitalis intoxication, because magnesium stimulates membrane ATPase.

In animal experiments several authors have shown an increased tolerance of digitalis when magnesium was administered at the same time (Zwillinger, 1935; Szekely, 1946; Szekely and Wynne, 1951). In man, however, the effect of magnesium in suppressing digitalis toxicity has so far been demonstrated in only a few cases with moderate overdosage (Lim and Jacob, 1972).

\section{References}

Beck, O. H., Krämer, K-D., and Hochrein, H. (1974). Verlauf einer suizidalen Digoxin-Intoxikation mit hyperkaliämie. Deutsche medizinische Wochenschrift, 99, 756-764.

Bergström, J. (1962). Muscle electrolytes in man. Scandinavian fournal of Clinical and Laboratory Investigation, 68, Suppl., 110.

Bergström, J., and Bittar, E. E. (1969). The basis of uremic toxicity. In The Biological Basis of Medicine, Vol. 6, p. 495. Ed. by E. E. Bittar and N. Bittar. Academic Press, New York.

Bismuth, C., Gaultier, M., Conso, F., and Efthymiou, M. L. (1973). Hyperkalemia in acute digitalis poisoning: prognostic significance and therapeutic implications. Clinical Toxicology, 6, 153-162.

Bolte, H. D., Riecker, G., and Röhl, D. (1963). Messungen des Membranpotentials an einzelnen quergestreiften Muskelzellen des Menschen in situ. Normalwerte. Klinische Wochenschrift, 41, 356-359.

Bonting, S. L., Caravaggio, L. L., and Hawkins, N. M. (1962). Studies on sodium-potassium-activated adenosinetriphosphatase IV. Correlation with cation transport sensitive to cardiac glycosides. Archives of Biochemistry and Biophysics, 98, 413-419.

Buchanan, J. (1967). Self-poisoning with digitalis glycosides. British Medical fournal, 3, 661-662.

Conway, E. J. (1957). Nature and significance of concentration relations of potassium and sodium ions in skeletal muscle. Physiological Reviews, 37, 84-132.

Doherty, J. E., Perkins, W. H , and Flanigan, W. J. (1967). The distribution and concentration of tritiated digoxin in human tissues. Annals of Internal Medicine, 66, 116-124.

Graham, J. A., Lamb, J. F., and Linton, A. L. (1967). Measurement of body water and intracellular electrolytes by means of muscle biopsy. Lancet, $2,1172-1176$.
Kleiger, R., and Lown, B. (1966). Cardioversion and digitalis. II. Clinical studies. Circulation, 33, 878-887.

Langer, G. A. (1972). Effects of digitalis on myocardial ionic exchange. Circulation, 46 180-187.

Lim, P., and Jacob, E. (1972). Magnesium deficiency in patients on long-term diuretic therapy for heart failure. British Medical fournal, 3, 620-622.

Lown, B., Black, H., and Moore, F. D. (1960). Digitalis, electrolytes and the surgical patient. American fournal of Cardiology, 6, 309-337.

Lown, B., Kleiger, R., and Williams, J. (1965). Cardioversion and digitalis drugs: changed threshold to electric shock in digitalized animals. Circulation Research, 17, 519-531.

Lown, B., and Levine, S. A. (1954). Current concepts in digitalis therapy. New England fournal of Medicine, 250, 771-779, 819-832, and 866-874.

McNamara, D. G., Brewer, E. J., Jr., and Ferry, G. D. (1964). Accidental poisoning of children with digitalis. New England Fournal of Medicine, 271, 1106-1108.

Mason, D. T., and Braunwald, E. (1968). Digitalis : new facts about an old drug. American fournal of Cardiology, 22, 151-161.

Page, E. (1964). The actions of cardiac glycosides on heart muscle cells. Circulation, 30, 237-251.

Repke, K. (1965). Effects of digitalis on membrane ATP-ase of cardiac muscle. In Proceedings of the Second International Pharmacological Meeting, pp. 65-87. Ed. by H. Rasková. Pergamon Press, Oxford.

Rosen, M. R., Gelband, H., and Hoffman, B. F. (1973). Correlation between effects of ouabain on the canine electrocardiogram and transmembrane potentials of isolated Purkinje fibers. Circulation, 47, 65-72.

Smith, T. W., Butler, V. P., Jr., and Haber, E. (1969). Determination of therapeutic and toxic serum digoxin concentrations by radio-immunoassay. New England fournal of Medicine, 281, 1212-1216.

Smith, T. W., and Willerson, J. T. (1971). Suicidal and accidental digoxin ingestion. Report of five cases with serum digoxin level correlations. Circulation, 44, 29-36.

Spector, W. S. (1956). (Ed.) Handbook of Biological Data. W. B. Saunders, Philadelphia and London.

Steentoft, A. (1973). Fatal digitalis poisoning. Acta Pharmacologica et Toxicologica, 32, 353-357.

Surawicz, B., and Mortelmans, S. (1969). Factors affecting individual tolerance to digitalis. In Digitalis, p. 127. Ed. by B. Surawicz and C. Fisch. Grune and Stratton, New York. Szekely, P. (1946). The action of magnesium on the heart. British Heart fournal, 8, 115-124.

Szekely, P., and Wynne, N. A. (1951). The effect of magnesium on cardiac arrhythmias caused by digitalis. Clinical Science, 10, 241-247.

Widdowson, E. M., and Dickerson, J. W. T. (1964). Chemical composition of the body. In Mineral Metabolism V.2, Part 2A, p. 1. Ed. by C. L. Comar and F. Bronner. Academic Press, New York and London.

Zwillinger, L. (1935). Uber die Magnesiumwirkung aud das Herz. Klinische Wochenschrift, 14, 1429-1433.

Requests for reprints to Dr. T. Dyckner, Med. Klin., Serafimerlasarettet, Box 12700, 11283 Stockholm, Sweden. 